\title{
MODELING INFORMATION SYSTEM FOR AGROINDUSTRY OF JAMU MADURA
}

\author{
Khoirul Hidayat \\ Department of Agroindustrial Technology, Faculty of Agricultural \\ Trunojoyo University, Indonesia \\ e-mail : irul_ie@yahoo.co.id \\ Received: April 18, 2018. Approved: June 15, 2018. Published: June 29, 2018 \\ (C)2018 -TESJ Fakultas Teknik Universitas Maarif Hasyim Latif. This article is open access \\ licensed under a CC BY 4.0 (https://creativecommons.org/licenses/by/4.0/)
}

\begin{abstract}
Jamu Payung Emas Siti Fatma vepretty much mastered the markets, especially in the area of East Java. With the development of Jamu Payung Emas Siti Fatma industry, the required data processing system more regularly so as to facilitate the herbal medicine industry is in a store all the information related to the production. Therefore, it is necessary to do research on agro-industry system design information Jamu Madura. This research method using system development life cyrcle (SDLC) method. Preparation and storage database, using a MySQL the programming language used is PHP and interface design was created using LTE Admin Template the editor is Sublime Text. The results of this study indicate that the design of information systems agroindustrial of Jamu Madura require ten entities are tables on leave, the employee table, the table stops working, the product table, table sales detail, table salaries, tables other expenses, entry table another table the bill of sale, and the table notes production. Each entity has a data type that has been tailored to the needs of data and linked with other entities that have relevance to make the system completely. Ten of these entities then designed and built the system up into four modules, namely modules personnel (containing sub-modules of employees, submodule salaries, submodule off, and submodule stops working), production modules (containing submodule products and submodule production records), marketing modules (containing submodules, and submodules sales note monthly demand), and the financial module (submodule contains other income and other expenses submodules). In each submodule, there are several actions that menu adds, edit, delete, and print so that users can monitor and control the company's system more easily.
\end{abstract}

Keywords : information system, agroindustry, jamu madura

\section{INTRODUCTION}

Indonesia is widely known as megacenters biodiversity ubiquitous plant is considered to have efficacy as a drug. One of the preparations of drugs found in Indonesia is herbal medicine. Herbal medicine has been used widely by the people of Indonesia to maintain health and overcome disease Today the development of traditional herbal medicine industry is increasing, traditional herbal medicine itself is one of the drugs that are herbs which contain no chemicals and is derived from medicinal plants are efficacious. Jamu traditional widely consumed due to the lack of side effects and the price is likely to be cheaper than chemical drugs. Producers of traditional herbal medicine have a lot to market their products by opening depots special herbs with the brands they own even existing production reaching international markets to export its products abroad.

Jamu traditional is one of the herbal remedies that come from Indonesia. Jamu has been used widely by the people of Indonesia to maintain health and overcome various diseases since centuries ago long before the era of Majapahit. Nowadays, the development of herbal industry tends to increase, both at home and abroad. Herbs companies started popping up in various regions, triggering the emergence also new medicinal herbs that are also nutritious for health, not only in Indonesia but also in different countries, such as countries in the ASEAN region.

The continued development of the herbal medicine industry in Indonesia, then the need for the data collection method or a regular recording to obtain the appropriate data in the herbal medicine industry. But in fact, the process of data collection in the herbal medicine industry for now still considered quite lacking for most of the herbal medicine manufacturers still rely on manual data collection process so much less accurate. Data processing activities of the herbal industry will be effective and efficient if it is only done by hand. The data processing can be done to facilitate herbal 
manufacturer one of them is using software specialized such as MS Access, which is designed to process data that is a database.

The data itself is a fact about objects, people, and others, while the database is a collection of data, which can be described as the activity of one or more organizations that are related. With the help of MS. Access is based database of the herbal industry is facilitated in the data collection process in the industry, both the data collection process of production, the collection of employees, as well as data collection product sales. Basically, a lot of the benefits if a company or industry to apply the processing of database using MS. Access such as that reduces the task to be done by a human or an employee in data processing as well as to provide information more quickly and accurately.

One of the producers of herbal medicine that is quite famous in Madura is "Payung Mas Siti Fatma". Jamu Payung Mas Siti Fatma vepretty much mastered the markets, especially in the area of East Java. With the development of this herbal industry, the required data processing system more regularly so as to facilitate the herbal medicine industry is in a store all the information related to the production. Therefore, it is necessary to research on agroindustrial system design information of jamu Madura.

\section{METHODS}

This research method using system development life cyrcle (SDLC) method. Data collection is done by observation field (observation directly or indirectly). Direct interviews conducted with the owner of the company or the employees of the company to acquire the company's data. The required data is sales data, employee data, administrative data, and others. Moreover, it also needs information on how companies conduct sales, production, and so forth. Study literature or literature which forms gathering phase secondary data such as journals, books, documents the agency used to support the analysis of primary data and correlate theory with field conditions. Required literature is literature about the stages of system design database.

Processing and analysis of data is an activity to process data into information so that the characteristics or properties of the data can be easily understood and used to address issues related to research activities. Before processing the data necessary to identify all the necessary requirements so as to produce the main features of the system. The picture then made the conceptual design and physical design, then created a model system in the form of a computer program and verified using the data obtained to perform simulations that appropriate and in accordance with the model that has been designed previously.

The data used in this study is the product sales data from January 2016 to December 2017. The sales data obtained from the bill of sale. In addition to sales data, the data used is the employee's identity data and data products. Based on the data obtained, then determined what entity is needed in designing the system, and also determined the attributes of what is needed in each entity. For example, the entity employees have employee id attribute, name, place, and date of birth, sex, religion, home address, and phone number. Once created entities and their attributes, then connected between entities so as to form a groove. The conceptual design is created using PowerDesigner. Physical design is generated from the conceptual design. Entities that are connected are components that need information or other data from components or other related entities. For example, in addition to financial entities composed of attributes contained in it, also require data from other entities such as the bill of sale, other income, memorandum expenditure, salaries, stop working, and other expenses. Data obtained as well as designs that have been made and then implemented into the database. Preparation and storage database, using a MySQL the programming language used is PHP and interface design was created using LTE Admin Template the editor is Sublime Text. The design of the model that will be created as the interface design includes several modules, namely modules personnel, production module, marketing module and the financial module.

Personnel module is a module that can manage employee data information and human resource management. This module contains about all matters relating to the company's human resources, namely in the form of employee identity data, salary, leave and stop working. Fourth it will be a submodule on personnel module. Employee identity data on employee submodules can be added, edited, deleted, and printout. While data on the submodules salary, leave and stop working has been created a form to enter the data and tables to see the results of the input. Production module contains two submodules is submodule and submodule product production records. Submodule products containing the names of the product and the net. Product data can be added, edited, removed, and, print. The names of the products included in the database are the products that were sold in January 2016 to December of 2017 , that there are as many as 14 products. Submodule contains production notes about the time of production, production capacity, and the number of products produced. In submodule production notes made form and tables production 
records. Marketing modules memorandum contains submodules and submodules of product sales demand monthly which is the number of sales per month on each product. Form to fill data in the bill of sale is made the same as that used by the memorandum of jamu Madura industry. In the memorandum can be filled several products. The sale is then separated by the system automatically based on the name of the product and the month of purchase. Disaggregated data is then used as a submodule demand monthly. Submodule demand monthly can be printed out but cannot add, edit, or delete data. Data can be added, edited, or removed through the fill data in submodule sales note. Financial module is a module that records revenue in addition to product sales and financial expenses of the company.

\section{RESULT AND DISCUSSION}

Jamu Madura "Payung Mas Siti Fatma" stand 1908 at the RA. Kartini 12 Bangkalan Madura. The industry was established for generations from mother Fatma family, the mother of his wife Dra. Titik Garin. Herbal products produced beginning only in the form of herbal powders that are distributed in the area of Madura. But along with the times, the consumer demand for packaging using the capsule is increasing. So now, the Jamu Madura "Payung Mas Siti Fatma" markets its products in capsule form. Marketing distribution is increasingly extended to East Java. Supplier of raw materials such as herbs taken in the area of Madura and Surabaya Customs Markets.

Madura herbal products marketed through the outlets and direct sales. In addition to herbs in capsule form, this industry also produces secang tea beverage is rich in benefits. Secang tea marketing is done through direct sales using a pickup. Herbal price offered was varied, namely between Rp. 50,000 Rp. 450,000. Pricing is conducted with the retail system, the party, and the unit. Employees working in this herbal industry as much as 7 people, all of whom are female. The data input process sales and purchases are still done manually. Booking herbal did directly through contact person Mr. Garin.

Traditional Jamu Madura production process is as follows; (1) Procurement of raw materials, procurement of raw materials in the production process of herbs in the herbal medicine industry Madura"Payung Mas Siti Fatma" is obtained through the process of purchasing raw materials from the collectors of medicinal plants around the town of Bangkalan and Customs Spice Market in Surabaya. (2) trashes won't, some types of bulbs need to undergo a process of cutting. Cutting crude drug material made to simplify the process of drying, packing and grinding. The new plant is taken not immediately chopped but dried intact for a day. Cutting can be done with a knife, with a special chopper machine tool in order to obtain thin slices or pieces to the required size. (3) Drying, drying aim to get bulbs that are not easily damaged, so it can be stored for a longer time. The drying is done by using the sun or using a dryer. Drying wrong way can lead to a"Face hardening", the outside of the material is dried while the inside is still moist. This can be caused by a crude drug material slices are too thick, the drying temperature is too high, or by any other state, so that the surface of the material to be loud and hinder the subsequent drying. "Face hardening" can result in damage or decay in part at the dried material. (4) Sorting dry, dry sorting aimed at separating foreign objects such as parts of the unwanted plants and other debris that still exist in the dry bulbs. As with the initial sorting, sorting dried herbs Madura "Payung Mas Siti Fatma" can be done manually or by several employees. (5) Packaging, which is used in herbal medicine place Madura "Payung Mas Siti Fatma" should not affect the material stored in it, both physically and chemically, which may result in changes in the strength, quality or purity to not meet official requirements. Points covered either have to protect the contents against the entry of solid material and prevent loss of material during handling, transportation, storage, and distribution. Packaging capsules are safe for consumption directly by consumers. (6) Storage, products that have been packaged in large plastic bags stored in warehouses. Storage is done in a room closed but the lighting was quite against insects as well as the appropriate temperature to room temperature. Madura storage shed medicinal product "Payung Mas Siti Fatma" in which there is a large shelf to store and prepare the product. It is intended that the product is not in contact with the floor.

Database management system serves as inclusion, deletion, central storage, processing, organizing, editing, callings, and providing data as an input model. The process of creating a database requires a determination of the stage of data needs. Determining the needs of the data in this study using a process-oriented approach. The steps used in determining data requirements using this approach is that first, define the problem. Then the next step is to identify the necessary decisions. After that outlines the information required for each decision. Next, determine the processing needed to produce information, and the last step is to determine the requirements specification data requested by processing (McLeod and George, 2007).

Following the steps of determining the needs of the data, obtained a decision on the data 


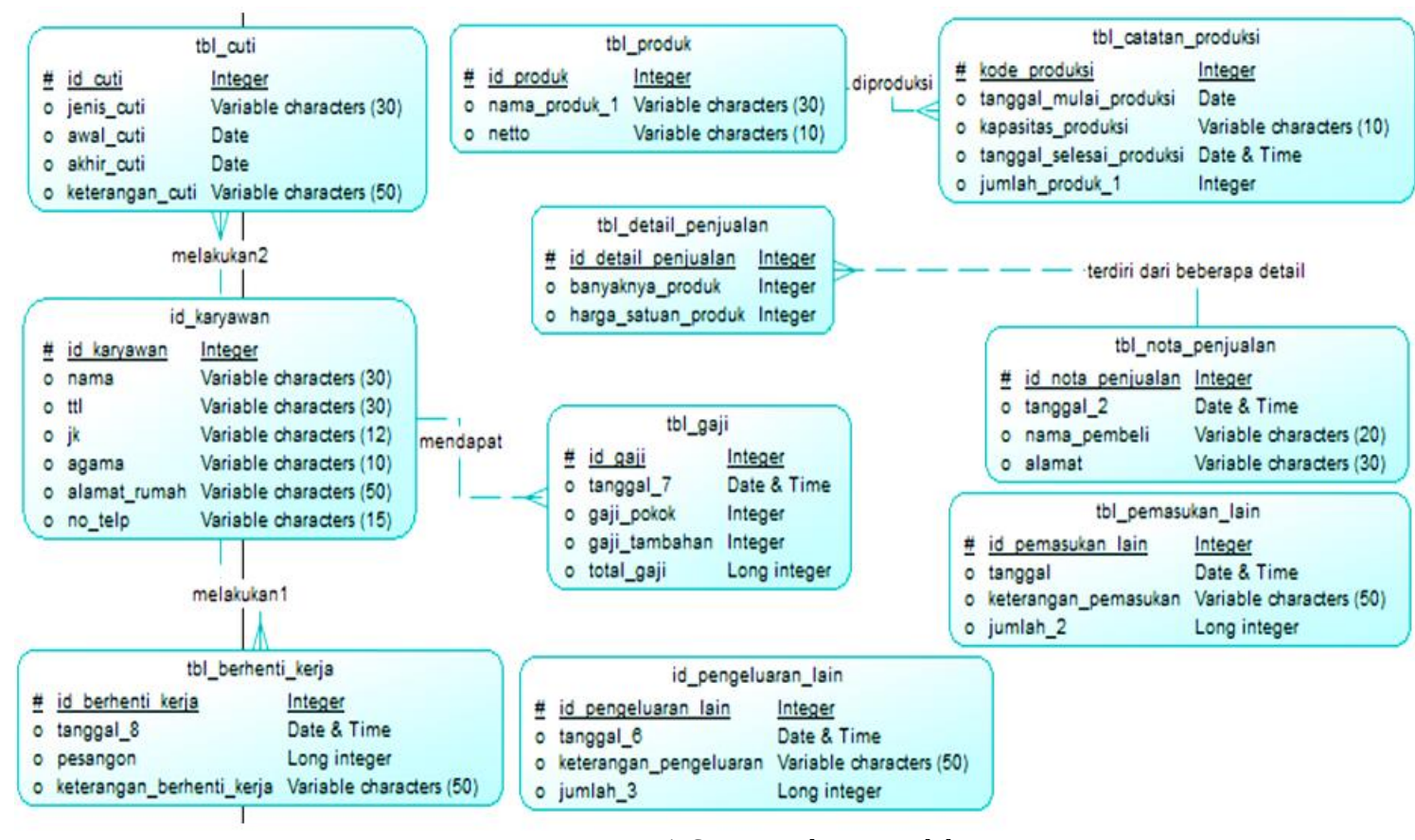

Figure 1. Conceptual Data Model

what is needed is a data record of sales per day, the data records per production, the data specifications of the product, the identity data of employees, payroll data, the data leave data to retire or quit labor, and financial data. The requirement specification required data described in the conceptual design.

The model describes the conceptual system design modeling tool, such as the Data Flow Diagram (DFD), Entity Relationship Diagram (ERD), decision table, screen prototype of the report, decision tree, and others. In this study, the conceptual design is done ERD or entity relationship diagrams. ERD shows the relationship of data in the entities and relationships between entities. ERD also disclose which entities should be connected with other entities conceptually (McLeod and George, 2007). The application used to create the conceptual design is PowerDesigner.In Power Designer are provided the tools used to design a conceptual easily called Conceptual Data Model (CDM). The conceptual design for the manufacture of agro-industrial information systems herbs Madura is as follows in Figure 1.

In conceptual design to use multiple data types. The data type that is widely used by the author is an integer and variable characters. Integer is a data type that can only contain numbers. Integer is used as a data type for each primary key so that if the user wants to add data, then id be the primary key can be filled automatically. A maximum limit on code integer that is 11 characters. Variable characters (varchar) is a data type that can contain letters and numbers. Varchar more widely used because the user can fill in data in the form of letters or numbers with a character limit that can be determined.

Entities related to the entity's employees table stops working table that employees can do to stop working. Entities employee table is also associated with an entity that employees leave the table can leave more than one. In the design, relationships do give additional codes 1 and 2 as in the draft should not be any relationship and the name of the same data. In addition, the entity table is also associated with an entity employee salary table which employees can earn more than one occasion.

Entities related products table with the entity table production notes that the product can be produced several times so that the name of one of these products may be listed on more than one record production. Entities related sales detail table with the entity table that is in a sales note sales note may contain some details of product sales, or the sales note is composed of some details of the sales. In the design of the entity table, there are also other income and other expenses entity table. Both of these entities are not created relationships because the data from these entities are not mutually exclusive.

Relationships between entities are one to many relationships with the end of unbranched as one and the end of the relationship that branched out as many. Relationships between entities can be corrected by Power Designer whether it is correct or not, whether the determination of the location of the one to many, or writing the name of the data. Whether or not the conceptual design can be known when the draft already begenerated planto physical or logical design. 
Physical design or Physical Data Model is generating from a Conceptual DataModel. The design was created on a Conceptual Data Model then be generated to form Physical Data Model. If after processing cannot be found fault or error, the conceptual design is made is correct. Physical Data Model to be used in the structure of the database in MySQL.

In the physical design can be seen that an employee becomes a foreign key (fk) in the table on left, the table stops working, and the salary table. This means that the data of each employee by employee id required by these tables. Explanation of physical design similar to the conceptual design, only the name relations in conceptual design has been reworded by id employee who becomes a foreign key to another table. Similarly on the product id foreign key to the table record production and sales into a memorandum id foreign key to the sales details table.

Database model agroindustrial information system is handled by the database management using MySQL. Database management on this information system provides the facility to manipulate data as input, edit, save, and delete data.

A user must interact with the system to be able to run a system, and the user wants to see an attractive and easy to use. Making the interface using Admin Template LTE, the programming language used is PHP and use the software editor Sublime Text 3. Here's a picture to see:

Module personnel

personnel module is a module that can manage employee data information. This module contains about matters relating to the company's human resources. Personnel module has four submodules, the sub-modules of employees, salaries submodules, submodules on leave, and the submodule stops working.

\section{CONCLUSIONS}

After completing the design and manufacturing information system application design agroindustrial of Jamu Madura, it could be concluded that the design of information systems agroindustrial of Jamu Madura require ten entities that leave the table, employee table, the table stops working, the tables products, sales detail table, the table of salaries, other expenses table, another entry table, table sales note and table production records. Each entity has a data type that has been tailored to the needs of data and linked with other entities that have relevance to make the system completely. Ten of these entities then designed and built the system up into four modules, namely modules personnel (containing submodules of employees, submodule salaries, submodule off, and submodule stops working), production modules (containing submodule products and submodule production records), marketing modules (containing submodules and submodules sales note monthly demand), and the financial module (submodule contains other income and other expenses submodules). In each submodule, there are several actions that menu adds, edit, delete, and print so that users can monitor and control the company's system more easily.

\section{REFERENCES}

Agus, M., F, D. W., \& Yunanto, R. (2010). Perancangan Database Management System Penjualan Pada PT Samafitro Cabang Bandung Dengan Menggunakan Software Microsoft Visual Basic 6.0 Dan Microsoft SQL Server 2000 Berbasis Client Server. Bandung: Fakultas Teknik dan Ilmu Komputer Universitas Komputer Indonesia.

Bassil, Y. (2012). A Simulation Model for the Waterfall Software Development Life Cycle. International Journal of Engineering \& Technology, 2(5), 2049-3444. https://doi.org/10.15680/ijircce.2015.0305 013

Cahyono, D. (2010). Aplikasi Penyedia Layanan Informasi Industri dan Produk Hasil Industri di Kota Surabaya (Studi Kasus: Disperindag Kota Surabaya). Surabaya: Institut Teknologi Sepuluh Nopember.

Christian, S. V. M. E. (2014). Sistem Pendukung Keputusan Kenaikan Jabatan pada PT Bank Central Asia Tbk. (BCA) menggunakan Metode Analityc Heararchy Process. Semarang: Teknik Informatika Universitas Dian Nuswantoro.

Febriadi, B., \& Zamsuri, A. (2017). RDBMS Applications as Online Based Data Archive: A Case of Harbour Medical Center in Pekanbaru. In IOP Conference Series: Earth and Environmental Science (Vol. 97, p. 12050). IOP Publishing.

Irmawati, I., \& S., S. (2012). Upaya Perbaikan Sistem Pemrosesan Transaksi Rawat Inap. Jurnal Administrasi Kebijak. Kesehatan, 10(3), 181-186.

Jogiyanto, H. M. (2005). Analisis \& Desain: Pendekatan Terstruktur, Teori dan Praktik Aplikasi Bisnis. Yogyakarta: Andi.

Khan, H. A. (2013). Establishing a defect management process model for software quality improvement. International Journal of Future Computer and Communication, 2(6), 585

Lata, M., \& Kumar, R. (2010). An approach to 
optimize the cost of software quality assurance analysis. Constraints, 1(1.11), 130.

Li, A., \& Pan, Y. (2008). Management and spatial decision support system of farmland environment based on SaaS mode. Transactions of the CSAE, 24(supp. 2), 63-67.

Nahlah, \& Amiruddin. (2015). Sistem Informasi Perpustakaan Berbasis Ms Access pada Jurusan Administrasi Niaga Politeknik Negeri Ujung Pandang. 4(2): Jurnal Sainsmat, 4(2), 175-195.

O'brien, J. A. (2000). Introduction to information systems. McGraw-Hill Higher Education.

Octafian Tri, D. (2011). Desain Database Sistem Informasi Penjualan Barang Studi Kasus Minimarket Grace Palembang. Jurnal Teknologi Dan Informatika (Teknomatika), 1(2).
Organization, W. H. (2002). Traditional Medicine: Growing Needs and Potential. Geneva: World Health Organization.

Padmaningrum, D., Rahayu, W., \& Wibowo, A. (2013). Rancang Bangun Model Kelembagaan Agribisnis Padi Organik Dalam Mendukung Ketahanan Pangan.

Royce, W. W. (1987). Managing the development of large software systems: concepts and techniques. In Proceedings of the 9th international conference on Software Engineering (pp. 328-338). IEEE Computer Society Press.

Suyanto, A. H. (2015). Basis Data dan DBMS. Copyright Jurnal Komputer. 